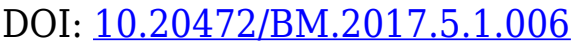

\title{
CROP INSURANCE MARKET IN HUNGARY
}

\section{RITA KOROSECZNÉ DR. PAVLIN, ANETT PARÁDI-DOLGOS, ZOLTÁN SIPICZKI}

\section{Abstract:}

This study makes a review of the agricultural risks management systems in Hungary with a special focus on agricultural insurances. We present the different types of agricultural insurances and analyze the structure of crop insurance market in Hungary.

The weather risks (example hail, drought, frost etc.) are the most significant uncertainty for agriculture enterprises. These risks are managed with agriculture insurance by the companies. Because of a high fee of insurance the enterprises insure themselves only for hail generally. In order to reduce the cost of insurance, Hungarian Government uses the establishment of a solidarity fund system and also the supporting system of insurance payment ex-post - in accordance with Common Agricultural Policy. Based on the rate of the aid there are 4 types of crop insurances on the market (the maximum level of this subsidy is $65 \%$ of the insurance fee).

We analyze in this study the market share of Hungarian agriculture insurance with the main focus on the subsidized insurance market.

\section{Keywords:}

crop insurance, agricultural risks management, subsidized insurance

JEL Classification: G22, H25, Q14

\section{Authors:}

RITA KOROSECZNÉ DR. PAVLIN, Kaposvár University, Hungary, Email: koroseczne.rita@ke.hu ANETT PARÁDI-DOLGOS, Kaposvár University, Hungary, Email: dolgos.anett@ke.hu ZOLTÁN SIPICZKI, Kaposvár University - Pallas Athene Domus Scientiae foundation, Hungary, Email: sipiczki.zoltan@ke.hu

\section{Citation:}

RITA KOROSECZNÉ DR. PAVLIN, ANETT PARÁDI-DOLGOS, ZOLTÁN SIPICZKI (2017). Crop insurance market in Hungary. International Journal of Business and Management, Vol. V(1), pp. 70-79., 10.20472/BM.2017.5.1.006 


\section{Introduction}

From the several types of agricultural risk the one in connection with the weather has special importance because the probability of extreme weather conditions is increasing from year to year as an the effect of the climate change. A harmonized agricultural risk management system has not yet been formulated in the European Union. (BardajiGarrido, 2016). That's why the member states apply different types of risk management tools in accordance with the $1^{\text {st }}$ and $2^{\text {nd }}$ pillar of the Common Agricultural Policy and the regulations about state aid.

The extraordinary weather-related fluctuations in yield take on in Hungary for a much larger extent than in other Western European countries (Pesti, 2009), so Hungary applies a wide range of risk management tools. In our study we analyse the crop insurance as one of the agricultural risk management techniques and we analyse the intensity of their state aid as well.

\section{Subsidies related to crop insurance in the European Union}

The support of the agricultural risk management has appeared in 2007 at the Common Agricultural Policy of the European Union at the first time. Initially, the harvest compensation was made available for fruit and vegetable sectors and the national wine programs. After that the Article 68 of regulation 73/2009/EC has extended the possibility of compensation to all agricultural sectors since 2008, but it has been applied only in France, Hungary, the Netherlands, and Italy. Besides the establishment of compensation schemes since 2012, in Hungary subsidies to the insurance premium have become available to farmers as well. This support was applied between 2012 and 2014, based on Article 68. 73/2009/EC regulation in Hungary. In 2015 as a block exemption subsidy was financed by the central budget. Since 2016 farmers can apply it as a rural development support in the framework of the Rural Development Plan.

In the $2^{\text {nd }}$ pillar of the Common Agricultural Policy the income stabilization tool appeared as a new element in addition to the supports of the mutual risk management fund and the fee subsidy of agricultural insurances. Analysis for the period 2014-2020 shows that Italy is the only, which uses all three tools and that is more than half of the planned EU level sources (EUR 1590.8 million). Sipiczki-Varga (2015) and VargaSipiczki-Bareith (2017) studies shown, stabilization the income of Hungarian agricultural farmers is crucial element of agricultural production. Hungary will introduce the income stabilization tool in addition to the insurance premium subsidy in the future, with which the risk management system will also be extended to livestock producers. This instrument will provide support for livestock farmers who suffer a loss of income of over 30 percent.

Hungary plans an amount of EUR 95.3 million for agricultural risk management supports based on the rural development plans in the period 2014-2020. More than this amount, only Italy (EUR 1590.8 million), France (EUR 600.7 million) and Romania (EUR 200 million) plan, among which Romania the only country that does not apply the insurance premium subsidy (Bardaji-Garrido, 2016). 


\section{Crop insurance schemes in Hungary}

The agricultural insurance portfolio makes 2.85 percent of the non-life insurance premiums in Hungary (HUF 10956 million), 87 percent of the sum is related to agricultural crop insurances (MABISZ, 2017). In Hungary producers can currently choose from four types of crop insurance schemes in order to manage the risks involved in crop production.

In the case of so-called traditional crop insurance scheme insurance companies already reimburse 10 percent reduction in yield as well. In this case the farmers' share of risk taking is small, so state aid cannot be provided for them. This construction is not dealt with in detail, because our study focuses on supported crop insurances.

Each insurance company formulates its offers on supported insurances in accordance with constructions of supportable insurances specified in the rural development plan. An insurance scheme can be supported if the insured event is a more than 30 percent yield reduction for each type of crops. So in this case, the 30 percent yield reduction covers farmers' willingness to take risks, regarding to which they are entitled to state support. After comparing the supported and unsupported constructions we can state: the essential element of support is that risks taken by insurance companies should be lower. Thus encourages insurance companies to take risks. In addition, farmers must assume a waiver from their claim to the extent of 30 percent yield loss in return to the state support.

Based on the different measures of risk taking and the different types of crops, insurance schemes can be divided into three state-supported groups („A", „B”, „C”). Hungary defined a HUF 23.7 billion envelope until 2020 for financing the No.17.1.1 Rural Development Program („Subsidies for crop insurance premiums”). This would allow to raise the budget of the subsidies from HUF 3 billion of 2015 (financed from the central budget ${ }^{1}$ ) to 4 billion of 2016 . The budget covers all of the three („A", „B”, „C”) supported insurance construction but the support-intensity is different in each cases. In the framework of the Rural Development Program the payment of the premium subsidies is follow-up. That's why as a first step the insurance companies formulate the insurance schemes („A”, „B”, „C") in accordance of the supporting program's requirements. After that the producers choose the types of dangers they want to insure. As a next step the suitable construction to the crop structure is defined. After signing the contract the producers can indicate the type of subsidized insurance schemes ("A", "B", "C") for each plots in the SAPS application. Based on the submitted application the Hungarian Agricultural and Rural Development Department records and verify the correctness of data. As a criteria for eligibility the farmer should pay off the whole amount of insurance premium until the $30^{\text {th }}$ of September in the given year. The Hungarian Agricultural and Rural Development Department should be informed about the payment by both partners. The support follows the payment of the annual insurance premium. The amount of the support is a given percent of the insurance premium, which is different in the three conditions. Its maximal scale is 65 percent, but because

\footnotetext{
${ }^{1}$ According to the agricultural Block Exemption Regulation (Kovács 2009).
} 
of the annual subsidy framework the actual rate may differ from the planned one. In the case of insurance condition "B" and "C" decrease can be experienced in the intensity. Its reason is the different level of risk taking for the different types of insurances. That's why in the followings we examine which insured events appear in the field of crop insurances and based on these what kind of constructions can be chosen.

\section{Risks and premium calculation of crop insurances}

The crop insurance schemes can be distinguished on the basis of types of damages. Insurance can be taken out for hail, flood, frost, storm and sand damage both individually and in aggregate as well. In Hungary especially hail damage has a high probability, which mainly occurs in the growing season of crops (AKI, 2010).

Insurance companies classify the individual plants into different risk categories. For instance green fodder has the lowest risk, winter wheat's risk is medium and vegetables and fruits have the highest risk. The insurance company assigns fix charges to the risks (the higher is the risk, the higher is the charge).

The insurance companies calculate the premiums based on the data defined by the farmers. The producers should tell on how much amount of yield they expect and at how much price they want to sell it after ripening. The so-called insurance amount is calculated as a multiplication of the market price and the expected yield. It means, the producers have such an insurance value. This insurance value will be weighted by a charge (\%) based on the risk classification of the crop. Finally the insurance premium is the multiplication of the charge and the insurance value. According to this, the calculation of insurance premium is the following:

Insurance premium $=$ covered area $*$ expected yield $*$ price $*$ insurance charge

Based on the data about arable crop production we can state, that in Hungary the twothirds of arable land is winter wheat and corn $(\mathrm{KSH}, 2016)$. Therefore in Table 2, we introduce the charges of the most common insurance events for these crops.

Table 1: The average rates associated with each loss events (Corn, cereal crops)

\begin{tabular}{|l|l|}
\hline Insurance event & Average insurance charge (\%) \\
\hline Hail damage & 1,4 \\
\hline Storm damage & 0,96 \\
\hline Fire damage & 0,115 \\
\hline
\end{tabular}

Source: own construction (AKI, 2010)

Data in Table 2 are consistent with the probability of the weather hazards in Hungary. We can see that insurance company charges the highest tariff in the case of the most likely damage, the hail damage. This charge is a little bit lower in the case of storm damage and fire damage is related to insignificant charges. After the description of the 
each types of damages we examine in details how they appear in the different types of supported crop insurance schemes.

\section{The types of the supported crop insurances}

"A" type crop insurance covers all type of damages, it includes hail, drought, flood, frost, rainstorm, storm and fire damages (NAK, 2016). In this scheme crops can be ensured which have a significant crop area in Hungary (corn, wheat, winter rapeseed rape, barley and sunflower). The following two types contain less danger elements.

In the case of " $\mathrm{B}$ " and " $\mathrm{C}$ " constructions only the hail, storm, winter frost and fire damages are insurance events. So in this two cases the insurance events are the same, they differ only in the range of crops. In the framework of type "B" arable crops, plantations and a significant part of vegetables can be insured. Type " $C$ " is available for all types of plants which cannot be insured by "A" or "B" constructions.

All of the three versions exist in significant number at the market so it is worth to examine the number of the contracts and the amount of the insurance premiums in each schemes. The following figure sums up the number of the contracts and the insurance premiums for the three constructions in 2016.

Figure 1: The distribution of the supported crop insurance constructions in 2016

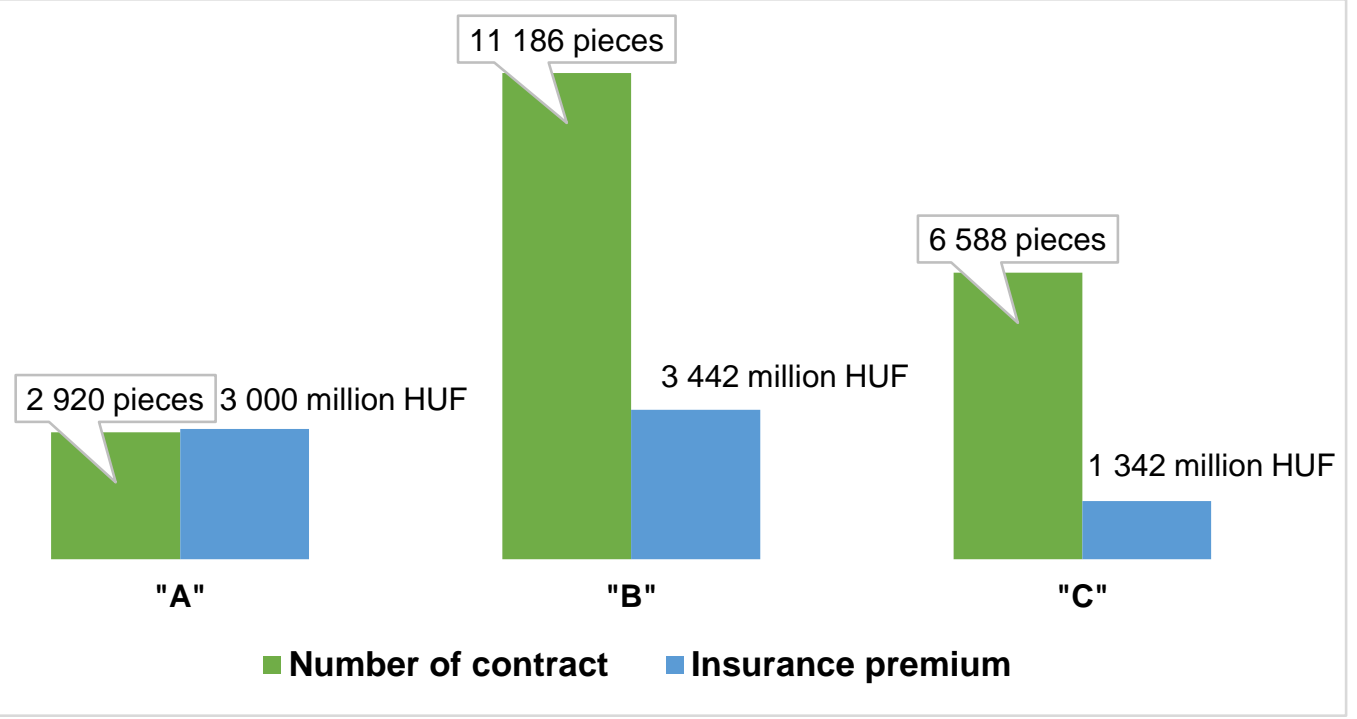

Source: own construction (Gazdag-Tanczné Óvári, 2017)

According to Figure 1 it is clear that among the subsidized crop insurance schemes the "B" is the most important with regard to the amount of insurance premiums and the number of contracts. This is because the type "A" contains a wide range of risk factors so it is much more expensive than "B". Producers, who choose the subsidized crop insurance, only choose type " $\mathrm{C}$ " for crops cannot be ensured with type "B". This leads to a kind of "normal distribution" and "B" excels from the three versions.

At the time of preparation of this study sufficient detailed data are not yet available, so in the following we introduce the Hungarian composition of the premium-supported crop insurances' market based on the data of 2015. In 2015 there was arable crop 
production on 3.756 thousand hectares of sown area in Hungary. 22 percent of these were covered with premium-supported crop insurance (838 hectare). A higher than the average coverage ratio can be experienced in the case of winter rape $(24 \%)$, the autumn durum wheat $(24 \%)$, soy $(32 \%)$, sugar beet $(34 \%)$ and tobacco $(34 \%)$ (AKI, 2016). By these crops in the case of adverse weather conditions not only the yield but also the quality can decrease significantly.

Based on type "B" and "C" insurances' detailed data we can observe that for which damages farmers make insurances. Figure 2. shows this in relation to 2015.

Figure 2: Coverage of „B" and „C" type insurances for the different types of damages (ha)

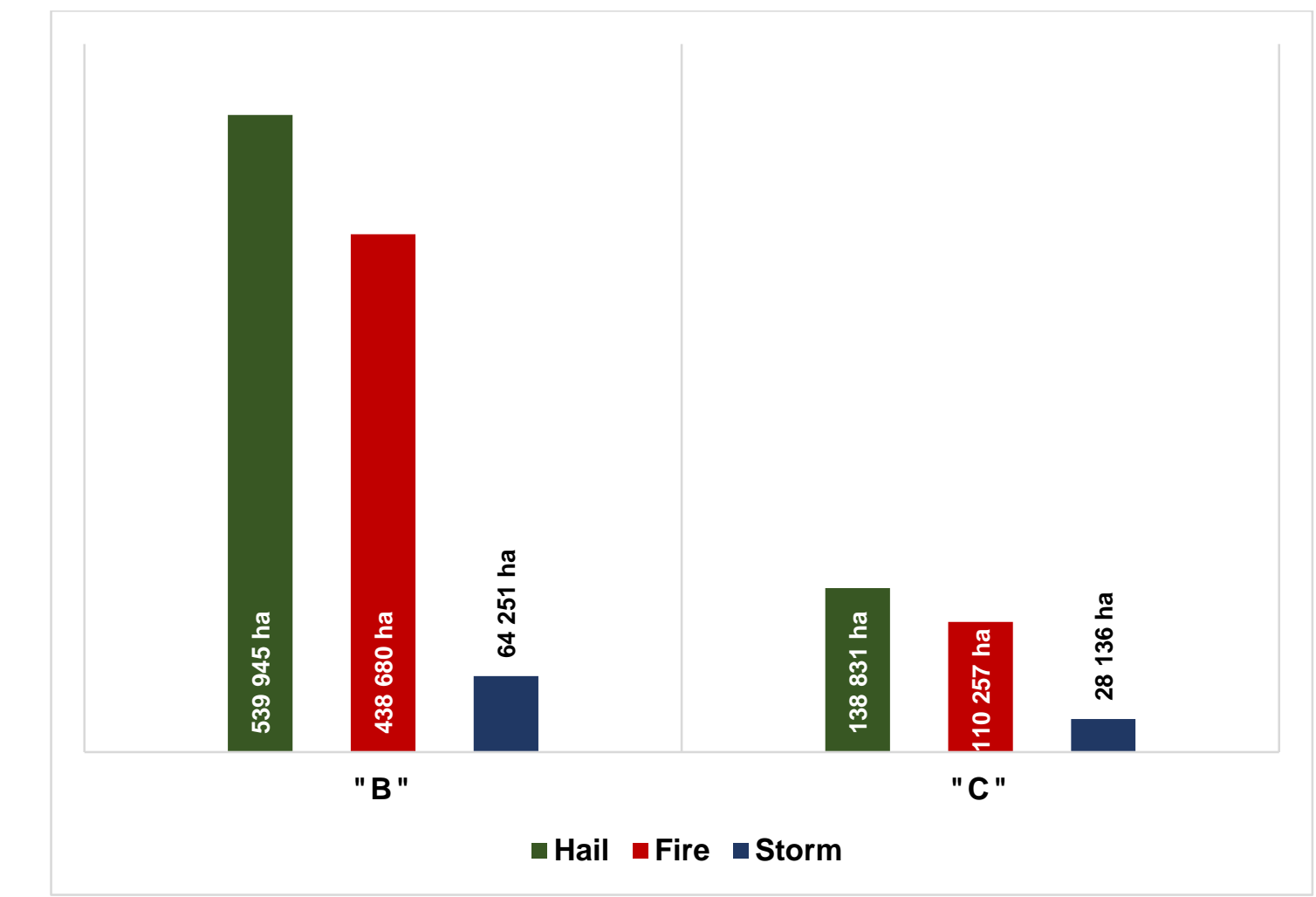

Source: own construction $(A K I, 2016)$

In 2015541.839 hectares of arable crops has been insured by "B" construction. Almost all of this (539 $945 \mathrm{ha}$ ) contained hail insurance elements. In addition the insurance for fire damage (438.680 ha) and storm damage (64.251 ha) were significant. For the risk of frost damage farmers take out insurances only on 3030 hectares in 2015 (AKI, 2016).

Comparing with type " $\mathrm{B}$ " in the case of the " $\mathrm{C}$ " construction we found a much smaller covered area, only 140.626 hectares in 2015 . Also almost all of this contains hail damage (138.831 ha), the cover for fire damage (110.257 ha) and storm damage (28.136 ha) are significant as well. The frost risk elements were insured only on 3.048 
hectares and for further risk elements ${ }^{2}$ were insured on 1671 hectares by the " $C$ " type of insurance. (AKI, 2016).

\section{The state's role in the crop insurance}

Based on the pre-defined envelope and the outstanding range of risk taking elements of insurance "A" it is clear that, not all producers are equally supported. Therefore, the state should regulate how to act in the case, if in the current year, the total amount of support's demand is higher than the envelope.

During the establishment of the supporting system it was a priority that all farmers can obtain a certain amount subsidy. So only its intensity can be reduced in the case of excessive applications. The minimal limits were defined for all types of insurances. So the redistributing regulation is as follows: in the case of excessive applications the intensity of type " $C$ " is reduced firstly until the minimum level, after that type " $B$ " and "A". Nowadays the Rural Development Program finances the system. According to the program subsidy intensity can be reduced until 55 percent in the case of type " $A$ " and until 40 percent in the case of type "B" and "C". Figure 3. shows the subsidy intensity for all three constructions since the introduction of the system.

Figure 3: Subsidy intensity of crop insurances

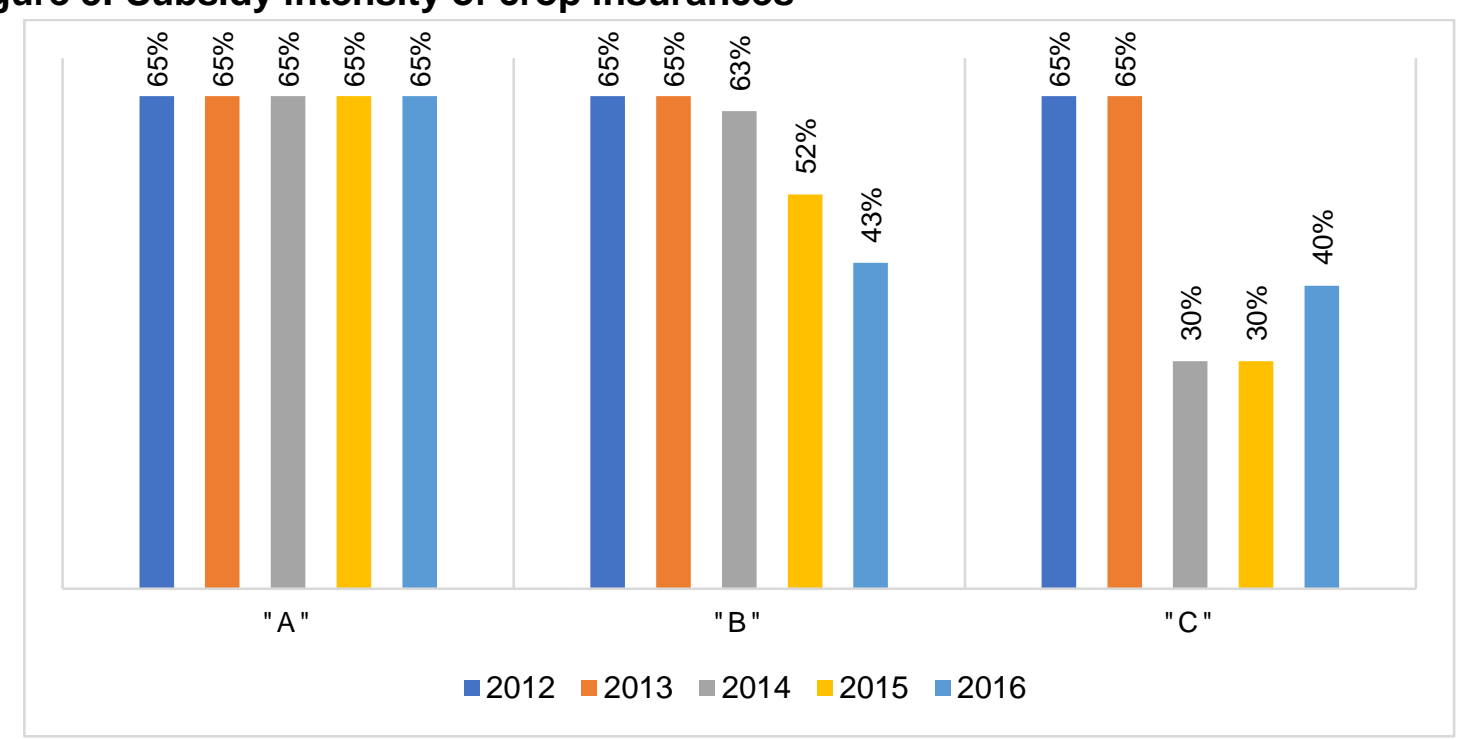

Source: own construction (Gazdag-Tanczné Óvári, 2017)

Before 2016 in the case of type "C" we can find 30 percent as well because in this period values defined in the Regional Development Program were not used. Due to the intensity increase of type " $C$ " the intensity of type " $B$ " reduced from 52 percent to 43 percent. Intensity reduction due to the excessive applications is clearly attributable to the increase of the contractors' number. The contracts of large companies stand in the background of the nearly $25 \%$ increase, because earlier they were excluded from the organisations could be supported.

\footnotetext{
${ }^{2}$ droughts, rainstorms, flood
} 


\section{Choose between the individual supported schemes}

In the following we examine in a farmer's point of view that how much cost they have with insurance premiums as a risk management tool, based on subsidy intensity of 2016.

Suppose that a farmer produces 500 hectares of corn and 250 hectares of rapeseed. In the latter case, "A" or "C" insurance can be used according to the rules. The producer choose type "B" for corn to reduce cost because this scheme can be used for corn and the farmer knows that type "B"'s subsidy intensity will be reduced only after type "C"'s one. In the case of corn the farmer calculates with a 6t/hectare average yield and with a 40000 HUF market price and in the case of rapeseed these numbers are $3 t$ and 100000 HUF. Charges defined by the insurance company are as follows: rapeseed in the case of a comprehensive insurance („A”) 7.295; rapeseed in the case of hail damage („C”) 3.15; in the case of corn („B”) 1.126.

$$
\begin{gathered}
\text { Insurance premium }_{\text {rapseed with } A}=250 \text { ha } * 3 t * 100000 \mathrm{HUF} * 7.295 \% \\
\text { Insurance premium }_{\text {corn with } B}=500 \text { ha } * 6 \text { tons yield } * 40000 \mathrm{HUF} * 1.126 \% \\
\text { Insurance premium }_{\text {rapseed with } \mathrm{C}}=250 \text { ha } * 3 t * 100000 \mathrm{HUF} * 3.15 \%
\end{gathered}
$$

Based on these data insurance premium and the supports for each schemes can be

\begin{tabular}{|c|c|c|c|c|c|c|c|}
\hline \multirow[t]{2}{*}{$\begin{array}{c}\text { Type of } \\
\text { insurance }\end{array}$} & \multirow[t]{2}{*}{ Crop } & \multicolumn{2}{|c|}{ Insurance premium } & \multicolumn{2}{|c|}{ Subsidy } & \multicolumn{2}{|c|}{$\begin{array}{l}\text { Insurance premium } \\
\text { reduced with } \\
\text { subsidies }\end{array}$} \\
\hline & & „A"+"B" & "B"+"C" & „A"+"B" & "B"+"C" & „A"+"B" & "B"+"C" \\
\hline$A$ & rapeseed & 5471250 & & 3556313 & & 1914938 & \\
\hline B & corn & 1351200 & 1351200 & 581016 & 581016 & 770185 & 770184 \\
\hline C & rapeseed & & 2362500 & & 945000 & & 1417500 \\
\hline & Total & 6822450 & 3713700 & 4137329 & 1526016 & 2685122 & 2187684 \\
\hline
\end{tabular}
defined. The following table summarizes this.

Table 2: Support elements (HUF)

Source: calculation based on own data collection

In the case of rapeseed we can calculate with " $A$ " and " $C$ " schemes as well, therefore on the table we can see in details how much cost is it for the farmer, if he covers 250 hectares of rapeseed with insurance type " $A$ " or " $C$ ". Corn belongs to type " $B$ " in both cases so its insurance premium is the same. In the insurance company's point of view it is clear that premium income of construction " $A+B$ " is nearly twice as high as the income of construction " $\mathrm{B}+\mathrm{C}$ ". Admittedly, the first one has a broader risk taking as well.

Examining the table's data in the point of the state's role of view we can define that subsidy amount for the given farmer is nearly three times higher in the case of the insurance construction with a broader range of risk taking. 
The data of the table's last row show that based on subsidy intensity ${ }^{3}$ of 2016 the insurance cost of the producers increases with 497.428 HUF if he chooses the comprehensive " $A$ " type and not the " $C$ " one for hail damage. This means 2000 HUF extra cost/hectare for him. Comparing insurance premiums we can state that the premium subsidy of crop insurance significantly improve the producer's effectiveness in both cases. The producers ultimately pays 39.35 percent ("A+B") or 58.9 percent ("B"+"C") of the total insurance amount as an insurance premium. Naturally the postfinanced nature of the support raises issues concerning liquidity, but they are not significant enough to cause problems in the operation.

\section{Summary}

There aren't a single, unified agricultural risk management system in the European Union. Although the $2^{\text {nd }}$ pillar of the Common Agricultural Policy formulates three different tools for risk management for the period 2014-2020, but about the application is decided at the level of the member states.

Between 2014 and 2020 Hungary intends the $4^{\text {th }}$ largest amount for different types of agricultural risk management tools among the member states. In 2016 beside the operation of the damage compensation fund supported crop insurances are available as well.

This study covers specifically the supported crop insurance types used in Hungary. After introducing the three supportable insurance schemes we focused on the typical damages, on which the farmers take insurances. For this analysis we used the detailed data on crop insurance market. After that, examining the crop insurance constructions in point of view of the government's role, we introduced that the support intensity can differ from the planned value because of the subsidy envelope, but it cannot be reduced below a minimum level. We determined through an example that farmers get to a wide range of risk management tools with a much more favorable conditions compared to the market insurance premiums by the subsidized schemes. Which is clearly an incentive for the farmers' willingness of taking insurances.

The income stabilization system defined in the $2^{\text {nd }}$ pillar of the Common Agricultural Policy are going to be established in the future. In the framework of this the risk management system will involve the livestock keepers as well. Finally a hail prevention system are going to be established at national level beside the agricultural risk management subsidies. This system can reduce the formation of hail as a weather damage and it's likely to be appeared in the lower insurance premiums. Due to lower insurance premiums after the end of crop insurance supports in 2020 crop insurances will be affordable for farmers. Thanks to all of this the extreme weather-related yield fluctuation as an agricultural risk becomes reduced.

\section{References:}

BARDAJI, I.- GARRIDO, A. (2016): Research for Agri-Committee-State of play of risk management tools implemented by member states during the period 2014-2020: national and Eurpoean

\footnotetext{
3 „A": 65\%; „B”:43\%; „C”:40\%
} 
frameworks, Research Centre for Management of Agricultural and Environmental, download date: 02.03.2017.

http://www.europarl.europa.eu/RegData/etudes/STUD/2016/573415/IPOL_STU(2016)573415_ EN.pdf

GAZDAS, GY.-TANCZNÉ ÓVÁRI, CS. (2017): 2016-ban több, mint 2 milliárd forinttal nőtt a díjtámogatott biztosítások állománya, download date: 03.02.2017. https://www.agronaplo.hu/szakfolyoirat/2017/01/gazdasag/2016-ban-tobb-mint-2-milliardforinttal-nott-a-dijtamogatott-biztositasok-allomanya

KEMÉNY, G. - LÁMFALUSI, I. (2016): Az agrár-kockázatkezelési rendszer müködésének értékelése, Agrár Kutató Intézet, Budapest

KOVÁCS, T. (2009): Új lehetőség agrárvállalkozásoknak kedvezményes hitelgarancia igénybevételére. In: Galló, F. - Pataki, L. (szerk.) Agrártámogatások és pályázatok. Budapest: Raabe Kiadó.

PESTI, CS. (2009): A mezőgazdasági termelés területi egyenlőtlenségeinek vizsgálata, Gödöllö, Szent István Egyetem, PhD értekezés, 147. p.

VARGA, J.- SIPICZKI, Z. (2015): The Financing of the Agricultural Enterprises in Hungary Between 2008 and 2011. PROCEDIA ECONOMICS AND FINANCE \&:(30) pp. 923-931. IISES 3rd and 4th Economics and Finance Conference

VARGA, J.-SIPICZKI, Z. - BAREITH, T. (2017): A magyarországi agrárolló és agrárvállalkozások jövedelmezőségének szektrorális vizsgálata 2005-2015 közti időszakban. CONTROLLER INFO 5:(klsz) pp. 343-351.

MAGYAR BIZTOSÍTÓK SZÖVETSÉGE (2017): Magyar Biztosítók Évkönyve 2016, download date: 03.03.2017. http://www.mabisz.hu/images/stories/docs/publikaciok/evkonyv-2016-magyar.pdf

AGRÁR KUTATÓ INTÉZET (2010): A hazai mezőgazdasági biztosítási rendszer problémái és továbbfejlesztési lehetőségei, Budapest

OVIEW OF CAP REFORM 2014-2020 (2013): Agricultural Policy Perspectives Brief, download date: 03.03.2017. http://ec.europa.eu/agriculture/sites/agriculture/files/policy-perspectives/policybriefs/05_en.pdf

KÖZPONTI STATISZTIKAI HIVATAL (2016): Szántóföldi növények 2015, download date: 03.02.2017, http://www.ksh.hu/docs/hun/xftp/gyor/szn/szn15.html

NEMZETI AGRÁR KAMARA (2016): Harmadával nőtt a támogatott agrárbiztosítások összege, download date: 03.03.2017. https://www.nak.hu/agazati-hirek/mezogazdasag/146novenytermesztes/92887-harmadaval-nott-a-tamogatott-agrarbiztositasok-osszege

VP3-17.1.1-16-Mezőgazdasági biztosítás díjához nyújtott támogatás pályázati kiírása, download date: 03.03.2017 https://www.palyazat.gov.hu/vp3-1711-16-mezgazdasgi-biztosts-djhoz-nyjtotttmogats 